\title{
Oxytocin- and vasopressin-induced growth of human small-cell lung cancer is mediated by the mitogen-activated protein kinase pathway
}

\author{
C Péqueux, B P Keegan ${ }^{1}, M-T$ Hagelstein, $V$ Geenen, J-J Legros \\ and W G North
}

University of Liège, Center of Immunology, Laboratory of Neuroendocrinology, Institute of Pathology CHU-B23,

B-4000 Liège 1-Sart Tilman, Belgium

${ }^{1}$ Dartmouth Medical School, Department of Physiology, Lebanon, NH 03756, USA

(Requests for offprints should be addressed to C Péqueux, University of Liège, Institute of Pathology CHU-B23,+4, Centre of Immunology, Laboratory of Neuroendocrinology, B-4000 Liège 1-Sart Tilman, Belgium; Email: C.Pequeux@ulg.ac.be)

\begin{abstract}
Malignant growth of small-cell lung carcinoma is promoted by various neuroendocrine autocrine/ paracrine loops. Therefore, to interfere with this mitogenic process, it is crucial to elucidate the mechanisms involved. It is known that the oxytocin (OT) and vasopressin (VP) genes, normally transcriptionally restricted in their expression, are activated in small-cell lung cancer (SCLC), concomitantly with expression of their receptors (OTR, V1aR, V1bR/V3R and V2R). The aim of the present study was to characterize, in concentrations close to physiological and pharmacological conditions, intracellular signalling events triggered by OT and VP binding to their specific receptors in SCLC cells and to identify factors mediating OT- and VP-induced mitogenic effects on SCLC. Known agonists for OTR ([Thr ${ }^{4}$, Gly $\left.\left.^{7}\right] \mathrm{OT}\right)$ and V1aR (F180), in addition to OT and VP, were able to elicit increases in cytosolic $\mathrm{Ca}^{2+}$ levels and this effect could be blocked using an OTR antagonist (OVTA) or a V1aR antagonist (SR49059) respectively. There was no activation of the cAMP pathway detected after VP, dDAVP (a V2R agonist), or OT treatment. Stimulation of SCLC cells with OT and VP led to an increase of extracellular signal-regulated kinase (ERK) $1 / 2$ phosphorylation, maximal at $5 \mathrm{~min}$, and the subsequent phosphorylation of its downstream target $\mathrm{p} 90$ ribosomal $\mathrm{S} 6$ kinase $\left(\mathrm{p}^{\mathrm{RSK}} \mathrm{R}^{\mathrm{RS}}\right.$ ). Preincubation with OVTA and SR49059, and with inhibitors of phospholipase C (PLC), protein kinase C (PKC), mitogen-activated protein kinase/ERK kinase (MEK) $1 / 2$ and a $\mathrm{Ca}^{2+}$ chelator significantly reduced OT- and VP-induced ERK1/2 phosphorylations. OVTA, SR49059 as well as MEK1/2 and PKC inhibitors also downregulated OT- and VP-induced p90 ${ }^{\mathrm{RSK}}$ phosphorylation. In $\left[{ }^{3} \mathrm{H}\right]$ thymidine-uptake experiments, we subsequently observed that PLC, $\mathrm{Ca}^{2+}$, PKC and ERK1/2 are absolutely required for the OT- and VP-stimulated SCLC cellular growth process. In conclusion, the results presented here indicate that OT- and VP-induced mitogenic effects on SCLC are respectively mediated by OTR and $\mathrm{V} 1 \mathrm{aR}$ signalling and that this mitogenic signalling passes through the phosphorylation of ERK $1 / 2$ and p90 $0^{\mathrm{RSK}}$ in a PLC-, $\mathrm{Ca}^{2+}-$, PKC- and MEK1/2-dependent pathway.
\end{abstract}

Endocrine-Related Cancer (2004) 11 871-885

\section{Introduction}

As a basic component of oncogenesis, neuroendocrine tumour cells usually develop very potent autocrine/ paracrine signalling pathways that play a crucial part in the dysregulation of cellular growth (Hanahan \& Weinberg
2000, Zochbauer-Muller et al. 2002). Among such autocrine/paracrine loops, the neurohypophysial peptide system is implicated in the pathogenesis of an increasing number of cancers and particularly in small-cell lung carcinoma (SCLC) (North 2000, Cassoni et al. 2001). Ligands of this system include the neurohypophysial 
hormones oxytocin (OT) and vasopressin (VP). There is only one known receptor for OT, OTR, and three main receptors for $\mathrm{VP}, \mathrm{V} 1 \mathrm{aR}, \mathrm{V} 1 \mathrm{bR} / \mathrm{V} 3 \mathrm{R}$ and $\mathrm{V} 2 \mathrm{R}$, by which respective hormones exert their physiological actions (Birnbaumer et al. 1992, Kimura et al. 1992, de Keyzer et al. 1994, Sugimoto et al. 1994, Thibonnier et al. 1994, Jard 1998). Tumour production, secretion of VP and its mitogenic action on SCLC cellular growth are well documented (Woll \& Rozengurt 1989a, Sethi \& Rozengurt 1991, Friedmann et al. 1994, North 2000, Rozengurt 2002).

Moreover, it is now established that these tumours also express and secrete OT (North et al. 1993, Péqueux et al. 2002). In SCLC, OT and VP have been shown to induce a dose-dependent (from $1 \mathrm{nM}$ ) and time-persistent increase of tumour cell proliferation. This mitogenic effect of OT was completely abolished by the OTR antagonist $\left(\mathrm{d}\left(\mathrm{CH}_{2}\right)_{5}^{1}, \operatorname{Tyr}(\mathrm{Me})^{2}, \mathrm{Thr}^{4}, \mathrm{Orn}^{8}, \mathrm{Tyr}^{9}-\mathrm{NH}_{2}\right)$-vasotocin (OVTA) which when used alone induces a reduction of SCLC cellular growth (Péqueux et al. 2002). However, the subsequent signalling pathways involved in this OT-related mitogenic effect have not been fully investigated.

The biological effects of neuropeptides result from the activation of complex intracellular networks rather than linear signalling cascades (Heasley 2001, Rozengurt 2002). The OTR, V1aR, V1bR/V3R and V2R all belong to the superfamily of G-protein-coupled receptors (GPCRs), which are structurally characterized by seven transmembrane domains. These GPCRs form constitutive homoand heterodimers, although no differences in pharmacological and signalling properties have been shown as a result of these interactions (Terrillon et al. 2003, Devost \& Zingg 2004). The OTR, as well as the V1aR and V1bR/V3R, mediate phosphatidylinositol hydrolysis and cytosolic $\mathrm{Ca}^{2+}$ increase, whereas V2R is coupled to adenylate cyclase and the second messenger cAMP (Barberis et al. 1998). In certain cell types expressing OTR or V1aR, OT and VP can induce phosphorylation and activation of mitogen-activated protein kinases (MAPKs; Ohmichi et al. 1995, Chiu et al. 2002, Zingg \& Laporte 2003). All known neurohypophysial peptide GPCRs are expressed in SCLC (Friedmann et al. 1994, North et al. 1997, North et al. $1998 a$, 1998b, Péqueux et al. 2002). Moreover, all these receptors have the ability to bind $\mathrm{VP}$ and/or OT with varying affinity. Thus both ligands are capable of initiating signalling cascades mediated by either receptor (Barberis et al. 1999). Altogether, these data suggest that the neurohypophysial hormone system displays a high degree of complexity in the tumour modulation of SCLC cellular growth. Moreover, the oxytocinergic system (OT and OTR) is implicated in the growth modulation of various neoplastic cells where it may inhibit or stimulate cell proliferation. These discordant effects have the potential to be a consequence of the activation of different signal transduction pathways which result in increased cytosolic $\mathrm{Ca}^{2+}$ or the formation of cAMP (Bussolati \& Cassoni 2001, Cassoni et al. 2001, Cassoni et al. 2002). Additionally, the activation of particular signalling intermediates by the OTR depends on its localization inside or outside caveolin-enriched domains resulting in a mitogenic or antimitogenic response to OT stimulation, respectively (Guzzi et al. 2002, Rimoldi et al. 2003).

These data emphasize the crucial part played by transduction signalling in mediation of neuropeptide effects. Therefore, in order to clarify the mechanisms leading to SCLC cellular growth dysregulation, we investigated the OT- and VP-induced mitogenic responses and the activation of signal transduction mediators in H345 and H146 SCLC cell lines. Specific agonists and antagonists of the OT and VP GPCRs were employed to further dissect ligand-mediated receptor activation involved in SCLC cellular growth. In order to extrapolate our in vitro findings to relevant physiological and pharmacological conditions, we adhered strictly to the concentrations of OT and VP that would be observed in vivo. The maintenance of this appropriate concentration is crucial for delineating the specificity of ligand binding (i.e. OT and VP) to their appropriate receptors. These results show that the OT- and VP-induced mitogenic effects on SCLC are mediated largely by the OTR and the V1aR, respectively, and that their activation leads to increases in cytosolic $\mathrm{Ca}^{2+}$, but not in production of cAMP. OT and VP stimulation also results in the increased phosphorylation of extracellular signal-regulated kinases (ERKs) 1 $\left(\mathrm{p} 44^{\mathrm{MAPK}}\right)$ and $2\left(\mathrm{p} 42^{\mathrm{MAPK}}\right)$ and of $\mathrm{p} 90$ ribosomal S6

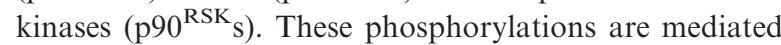
by phospholipase $\mathrm{C}$ (PLC)-, $\mathrm{Ca}^{2+}$-, protein kinase $\mathrm{C}$ (PKC)- and MAPK/ERK kinases (MEK1 and MEK2)dependent pathways.

\section{Materials and methods \\ Reagents and cell culture}

Dulbecco's PBS (DPBS), fetal calf serum and RPMI 1640 were purchased from Cambrex (Verviers, Belgium); OT and VP originated from Calbiochem (VWR, Leuven, Belgium). Desmopressin or (deamino-Cys ${ }^{1}, \mathrm{D}_{-\mathrm{Arg}^{8}}{ }^{8} \mathrm{VP}$ (dDAVP; a V2R agonist; Zaoral et al. 1967) and OVTA (an OTR antagonist; Manning et al. 1989) were obtained from Bachem (Bubendorf, Switzerland). F180 (a V1aR agonist; Aurell et al. 1990, Andres et al. 2002) was provided kindly by P. Riviere (Ferring Research, San Diego, CA, USA), [Thr ${ }^{4}$, Gly ${ }^{7}$ OT (an OTR agonist; Lowbridge et al. 1977) by M. Manning (Medical College of Ohio, Toledo, OH, USA) and SR49059 (a VlaR antagonist; Serradeil-Le Gal et al. 1993) by C. Serradeil-Le Gal (Sanofi Recherche, Montpellier, 
Endocrine-Related Cancer (2004) 11 871-885

Table 1 Neurohypophysial peptide agonist and antagonist $K_{\mathrm{d}}$ values in humans

\begin{tabular}{lllll}
\hline \multirow{2}{*}{ Ligands } & V1aR & V1bR/V3R & V2R & OTR \\
\hline VP & 1.0 & 0.7 & 3.3 & 1.6 \\
F180 & 11.7 & 2100 & $>10000$ & 520 \\
dVAVP & & & & \\
(1-deamino, 8-D-arginine)VP & 21 & 22 & 2.7 & 203 \\
SR49059 & 0.9 & 129 & 119 & 33 \\
OT & 146 & 1160 & 1540 & 0.8 \\
[Thr ${ }^{4}$, Gly $^{7}$ ]OT & 78.8 & - & - & 6.6 \\
OVTA $^{-10229}$ & 929 & 0.2 \\
\hline
\end{tabular}

Dissociation constant $\left(K_{\mathrm{d}}\right)$ values are taken from Barberis et al. (1999) and Andres et al. (2002)

France). Indo-1-AM (where AM is acetoxymethyl ester), EGTA-AM and ionomycin (4-bromo A-23187) were purchased from Molecular Probes (Eugene, OR, USA). Insulin-transferin-sodium selenite (ITS) solution (I1884), BSA (fraction V, A-4503), forskolin, isobutylmethylxanthine (a phosphodiesterase inhibitor) and glucose were obtained from Sigma. Complete ${ }^{\mathrm{TM}}$ proteaseinhibitor cocktail tablets were from Roche, $\left[{ }^{3} \mathrm{H}\right]$ thymidine was from Amersham Pharmacia Biotech and scintillation liquid from Perkin Elmer (Courtaboeuf, France).

The origins of the antibodies were as follows: polyclonal anti- $\beta$-actin (ab8227) was from Abcam (Cambridge, UK), and polyclonal anti-p42/44MAPK (ERK1/ 2; \#9102), polyclonal anti-phospho-p42/44 MAPK (ERK1/ 2; \#9101), polyclonal anti-phospho-p90 ${ }^{\mathrm{RSK}}$ (\#9344) and anti-rabbit IgG horseradish peroxidase-linked (\#7074) antibodies were from Cell Signaling Technology (Beverly, MA, USA). U73122 (a PLC inhibitor), GF109203X (a PKC inhibitor) and BAPTA-AM (bis-(o-aminophenoxy)ethane- $N, N, N^{\prime}, N^{\prime}$-tetra-acetic acid AM; a $\mathrm{Ca}^{2+}$ chelator) were obtained from BIOMOL Research Laboratories (Plymouth Meeting, PA, USA) and U0126 (a MEK1/2 inhibitor; \#9903) was from Cell Signaling Technology.

The classical SCLC cell lines NCI H345 and NCI H146 were purchased from American Type Culture Collection (Manassas, VA, USA). Cells were cultured in a humidified atmosphere of $5 \% \mathrm{CO}_{2}$ and $95 \%$ air at $37^{\circ} \mathrm{C}$, according to American Type Culture Collection recommended guidelines.

\section{Flow-cytometric analysis of $\mathrm{Ca}^{2+}$ kinetics}

H345 cells routinely cultured were washed twice with DPBS. Cells $\left(3 \times 10^{6}\right.$, cells $\left./ \mathrm{ml}\right)$ were loaded by incubating them for $45 \mathrm{~min}$ at $37^{\circ} \mathrm{C}$ in serum-free medium (RPMI 1640 + ITS $1 \%$ ) containing $5 \mu \mathrm{M}$ indo-1-AM. After two washes with DPBS, cells were suspended at $1 \times 10^{5}$ cells $/ \mathrm{ml}$ in a $\mathrm{Ca}^{2+}$ buffer made of DPBS containing $\mathrm{CaCl}_{2}(1 \mathrm{mM})$, glucose $(1 \mathrm{mg} / \mathrm{ml})$ and BSA $(0.1 \%)$. Loaded cells were kept at room temperature until flow analysis was performed on a Facstar plus flow cytometer (Becton Dickinson, Franklin Lakes, NJ, USA). Prior to analysis, loaded cells $(900 \mu \mathrm{l})$ were placed at $37^{\circ} \mathrm{C}$ for $2-5 \mathrm{~min}$. Fluorescence records of each sample were measured over approximately $4 \mathrm{~min}$, at an excitation wavelength of $356 \mathrm{~nm}$ and emission wavelengths of $405 \mathrm{~nm}\left(\mathrm{Ca}^{2+}\right.$-bound indo-1-AM) and $485 \mathrm{~nm}$ (free indo-1-AM). The various peptide ligands being tested (Table 1) were administered as $100 \mu$ volumes in $1 \mathrm{mM}$ $\mathrm{Ca}^{2+}$ buffer to cell samples after $30 \mathrm{~s}$ of baseline recording. Proper loading of the cells with indo-1-AM was confirmed (approximately $80-90 \%$ of responding cells) by stimulation with ionomycin (4-bromo A-23187; $10 \mu \mathrm{M}$ ), which induces $\mathrm{Ca}^{2+}$ influx from the extracellular medium. Incubation of the cells with EGTA-AM $(0.01 \mathrm{mg} / \mathrm{ml})$ $5 \mathrm{~min}$ prior to flow measurement, as well as administration of $\mathrm{Ca}^{2+}$ buffer without ligand, were used as suitable negative controls. Receptor activity was specifically blocked by pre-incubating the cells with antagonists of the OTR or $\mathrm{V} 1 \mathrm{aR}$ for $15 \mathrm{~min}$ at $37^{\circ} \mathrm{C}$ prior to measuring their baseline and agonist-stimulated cytosolic $\mathrm{Ca}^{2+}$ levels by flow cytometry. The agonists tested were OT (1 nM), VP (1 nM), F180 (V1aR agonist; $20 \mathrm{nM}$ ) and [Thr ${ }^{4}$, Gly $\left.{ }^{7}\right] \mathrm{OT}$ (OTR agonist; 5 nM). The antagonists were SR49059 (V1aR antagonist; $10 \mathrm{nM}$ ) and OVTA (OTR antagonist; $0.5 \mathrm{nM})$. Data were analysed using Flowjo 3.4 software (Tree Star, Ashland, OR, USA) and plotted as the ratio $405 \mathrm{~nm} / 485 \mathrm{~nm}$ expressed as the percentage of responding cells over a threshold of 200 (mean ratio $405 \mathrm{~nm} / 485 \mathrm{~nm}$ ) against time (s).

\section{cAMP kinetics}

Prior to cAMP analysis, H345 and H146 cells were cultured overnight in serum-free medium (RPMI $1640+$ BSA 0.1\% + ITS $1 \%$ ) at a density of $1 \times 10^{6}$ cells $/ \mathrm{ml}$ under normal conditions. The cells were then treated for periods from 0 to $60 \mathrm{~min}$ at $37^{\circ} \mathrm{C}$ with OT, VP or dDAVP (V2R agonist) in the presence of isobutylmethylxanthine $(50 \mu \mathrm{M})$. Treatment with the adenylate cyclase activator forskolin was 
performed as a positive control. OT, VP and dDAVP were tested at concentrations of $1 \mathrm{nM}, 10 \mathrm{nM}, 100 \mathrm{nM}$ and $1 \mu \mathrm{M}$ and forskolin was used at 1 and $10 \mu \mathrm{M}$. After the appropriate time, the reactions were stopped by centrifugation $\left(250 \mathrm{~g}, 4^{\circ} \mathrm{C}, 5 \mathrm{~min}\right)$. Supernatants were discarded and the pellets were washed with DPBS $\left(2 \mathrm{ml}, 4^{\circ} \mathrm{C}\right)$. After centrifugation, the cell pellets were lysed in $1 \mathrm{ml}$ ethanol $(95 \%) / \mathrm{HCl}(0.01 \mathrm{M})$ at $4^{\circ} \mathrm{C}$, and then vortexed three times for $20 \mathrm{~s}$. Samples were centrifuged $\left(13600 \mathrm{~g}, 4^{\circ} \mathrm{C}, 15 \mathrm{~min}\right)$ and the supernatants $(900 \mu \mathrm{l})$ were collected in $1.5 \mathrm{ml}$ tubes, lyophilized and stored at $-20^{\circ} \mathrm{C}$ until assayed. The cAMP content was determined using a RIA kit (RPA 509; Biotrak, Amersham Biosciences).

\section{Preparation of cell lysates and Western blot kinase phosphorylation analysis}

H345 and H146 cells in stock culture were washed in DPBS and seeded into 12-well plates in serum-free medium (RPMI $1640+$ BSA $1 \%$ ) at a density of $3 \times 10^{6}$ cells/well, and cultured overnight. Cells were preincubated in RPMI 1640 alone (control) or containing U73122 (PLC inhibitor; $2.5 \mu \mathrm{M})$, BAPTA-AM $\left(\mathrm{Ca}^{2+}\right.$ chelator; $20 \mu \mathrm{M}$ ), GF109203X (PKC inhibitor; $20 \mu \mathrm{M}$ ) or U0126 (MEK1/2 inhibitor; $10 \mu \mathrm{M}$ ) for $45 \mathrm{~min}$, or they were pre-incubated in RPMI 1640 containing OVTA (OTR antagonist; $0.5 \mathrm{nM}$ ) or SR49059 (V1aR antagonist; $10 \mathrm{nM}$ ) for $15 \mathrm{~min}$. Then, cells were stimulated with OT or VP at a final concentration of $1 \mathrm{nM}$ for the indicated period of time (basal control is unstimulated). Reactions were stopped by addition of ice-cold DPBS. Ice-cold DPBS and lysing buffer (20 mM HEPES, $150 \mathrm{mM} \mathrm{NaCl}$, $10 \%$ glycerol, $0.5 \%$ Triton $\mathrm{X}-100,1 \mathrm{mM}$ dithiothreitol, $1 \mathrm{mM} \mathrm{Na} \mathrm{VO}_{4}, 25 \mathrm{mM} \beta$-glycerophosphate, $1 \mathrm{mM} \mathrm{NaF}$ and 1 tablet $/ 50 \mathrm{ml}$ Complete ${ }^{\mathrm{TM}}$ ) were used to wash the cells twice and extract their protein. After centrifugation $\left(18000 \mathrm{~g}, 15 \mathrm{~min}, 4^{\circ} \mathrm{C}\right)$ supernatants were isolated and aliquots were assayed for protein content using the Bradford protein assay (BioRad). Cell lysates were conserved at $-20^{\circ} \mathrm{C}$ until Western blot procedure.

Cellular proteins $(20 \mu \mathrm{g})$ were separated by $10 \%$ SDSPAGE and Western transferred on to polyvinylidene difluoride (PVDF; Immobilon ${ }^{\mathrm{TM}}$-P; Millipore, Bedford, MA, USA) membranes. After activation in methanol $(100 \%)$, blots were incubated for $1 \mathrm{~h}$ at room temperature, in TBS-T (20 mM Tris/ $\mathrm{HCl}, 140 \mathrm{mM} \mathrm{NaCl}$ and $0.2 \%$ Tween 20, pH 7.6) containing 5\% powdered skimmed milk (Gloria ${ }^{\circledR}$; Nestlé, Switzerland; TBS-T/milk). After washing, membranes were incubated overnight at $4{ }^{\circ} \mathrm{C}$ with the appropriate primary polyclonal antibody (see legends of Figs 3 and 4 for specific antibodies) at a concentration recommended by the manufacturer, in TBS-T containing $5 \%$ BSA. After washing, the membranes were incubated for $1 \mathrm{~h}$ at room temperature with the horseradish perox- idase-linked anti-rabbit $\mathrm{IgG}$ diluted in TBS-T/milk, washed again, and the immunocomplexes visualized by chemiluminescence reaction $\left(\mathrm{ECL}^{\mathrm{TM}}\right.$ Western blotting Detection Reagents; Amersham Biosciences). For signal quantification, membranes were densitometrically scanned (Gs-700; BioRad) and analyzed with Quantity One 4.2.1 software (BioRad). Quantification of phosphorylated protein forms was carried out by expressing their intensity relatively to the intensity generated by $\beta$-actin or ERK $1 / 2$ immunoblotting and as a ratio of basal activation.

\section{Cell proliferation}

Cellular growth and toxicity were evaluated for the same experiment by respective measurement of $\left[{ }^{3} \mathrm{H}\right]$ thymidine incorporation into DNA and of lactate dehydrogenase (LDH) release in culture supernatants using a standard chemical procedure (Roche). H345 and H146 cells in stock culture were washed in DPBS and replated in T culture flasks $\left(25 \mathrm{~cm}^{2}\right.$; VWR, Belgium) in RPMI 1640 added with $5 \%$ charcoal-treated fetal calf serum (charcoal treatment discards small molecules and proteins such as OT and VP) at an initial density of $1 \times 10^{5}$ cells $/ \mathrm{ml}$ and cultured overnight. Then, RPMI 1640 (basal control), OT or VP were added in culture medium at final concentration of $1 \mathrm{nM}$. After $72 \mathrm{~h}$ of culture with hormone or solvent, U73122, BAPTA-AM, GF109203X, U0126 or DMSO (1/2000) diluted in RPMI 1640 (control) were added to culture medium at final concentrations ranging from 2.5 to $10 \mu \mathrm{M}$. After $30 \mathrm{~min}$ and $1,2,4,24,48$ and $72 \mathrm{~h}$ of culture with these inhibitors or solvent, $1 \mathrm{ml}$ cell suspension was taken and distributed in triplicate on 96well plates $(200 \mu \mathrm{l} /$ well $)$ for $\left[{ }^{3} \mathrm{H}\right]$ thymidine incorporation. The remaining cell-suspension fraction was centrifuged $\left(250 \mathrm{~g}, 20^{\circ} \mathrm{C}, 10 \mathrm{~min}\right)$, and $200 \mu \mathrm{l}$ supernatant was mixed with Complete ${ }^{\mathrm{TM}}$ protease-inhibitor cocktail and $50 \%$ glycerol (v/v) and stored at $-20^{\circ} \mathrm{C}$ till $\mathrm{LDH}$ assay.

$\mathrm{LDH}$ baseline and positive control were respectively LDH measures in culture medium or when $1 \mathrm{ml}$ cell suspension was lysed with RPMI 1640 with $2 \%$ Triton X100. On 96-well plates, $\left[{ }^{3} \mathrm{H}\right]$ thymidine $(25 \mu \mathrm{l}, 11.5 \mu \mathrm{Ci} / \mathrm{ml})$ was added and plates were incubated for $4 \mathrm{~h}$ in a humidified atmosphere of $5 \% \quad \mathrm{CO}_{2}$ and $95 \%$ air at $37^{\circ} \mathrm{C}$. Cellular DNA was harvested from the cells using a Titertek cell harvester (Flow Laboratories, McLean, VA, USA). One-minute sample counts were obtained in a Beckman liquid scintillation counter (Beckman, Fullerton, CA, USA).

\section{Statistical analyses}

Variations in $\left[{ }^{3} \mathrm{H}\right]$ thymidine uptake were analyzed statistically with GraphPad Prism ${ }^{\mathrm{TM}}$ software (GraphPad 
Software, San Diego, CA, USA), using ANOVA followed by Student-Newman-Keuls test.

\section{Results}

\section{OT- and VP-induced $\mathrm{Ca}^{2+}$ kinetics}

In order to assess whether OT, in addition to VP, could initiate in SCLC, under ligand concentrations within the range in vivo, the inositol-mediated pathway usually associated with OTR, V1aR and V1bR/V3R, changes in H345 cytosolic $\mathrm{Ca}^{2+}$ level were measured by flow cytometry. There was a $40 \%$ increase in the cytosolic $\mathrm{Ca}^{2+}$ levels observed in response to OT or VP at $1 \mathrm{nM}$
(Fig. 1). Specific activation of the OTR or the VlaR located in the H345 cell membrane was tested using receptor agonists at selective concentrations (see Table 1). Stimulation with $\left[\mathrm{Thr}^{4}\right.$, Gly $\left.{ }^{7}\right] \mathrm{OT}$ (OTR agonist) at $5 \mathrm{nM}$ or with F180 (V1aR agonist) at $20 \mathrm{nM}$ resulted in a clear increase $(35 \%)$ in cytosolic $\mathrm{Ca}^{2+}$ (Fig. 1). Depending on their concentrations, OT and VP can bind each of the neurohypophysial peptide GPCRs (see Table 1). To identify which receptor(s) mediate the OT- or VP-induced increase in cytosolic $\mathrm{Ca}^{2+}$, cells were exposed to OTR antagonist (OVTA) or V1aR antagonist (SR49059) at concentrations ( 0.5 and $10 \mathrm{nM}$ respectively) that selectively block those receptors (see Table 1). Cell preincubation with antagonists was followed by stimulation

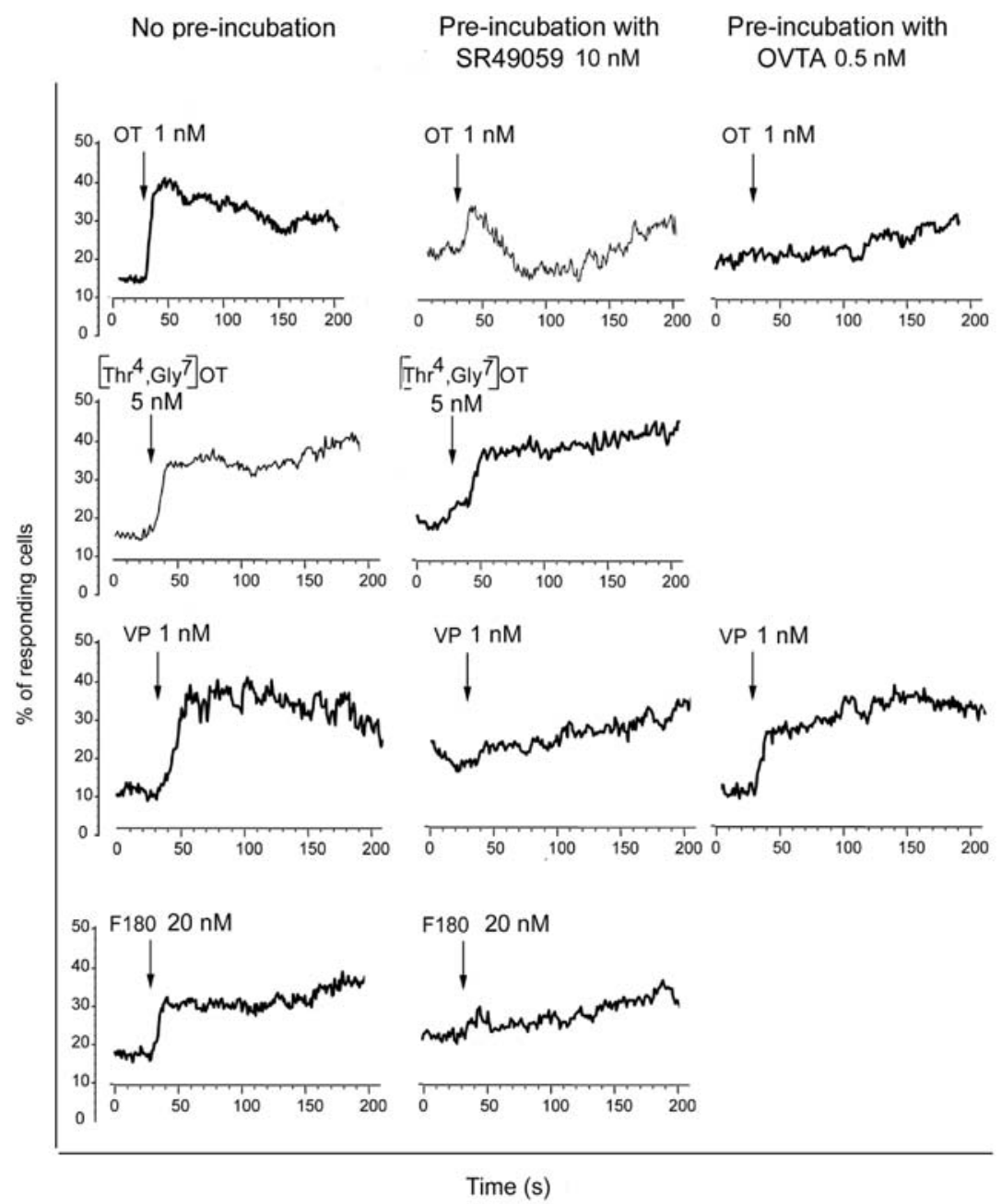

Figure 1 Effect of OT and VP on $\mathrm{Ca}^{2+}$ kinetics with or without antagonist pre-incubation. For antagonist pre-incubation, indo-1-AMloaded $\mathrm{H} 345$ cells were exposed to the V1aR antagonists SR49059 (10 nM), or the OTR antagonist OVTA (0.5 nM) for $15 \mathrm{~min}$ at $37^{\circ} \mathrm{C}$. Then, changes in cytosolic free calcium were measured using flow-cytometric analysis to determine the $405 / 485 \mathrm{nM}$ emissions ratio over a 200 -s period. After approximately $30 \mathrm{~s}$ of baseline, samples were injected with OT (1 nM), OTR agonist $\left[\mathrm{Thr}^{4}\right.$, Gly $\left.^{7}\right]$ OT $(5 \mathrm{nM})$, VP $(1 \mathrm{nM})$ or V1aR agonist F180 $(20 \mathrm{nM})$. Data are expressed as the percentage of responding cells over a threshold of 200 (mean ratio $405 \mathrm{nM} / 485 \mathrm{nM}$ ) against time (s). Kinetics shown are representative of two independent experiments. 

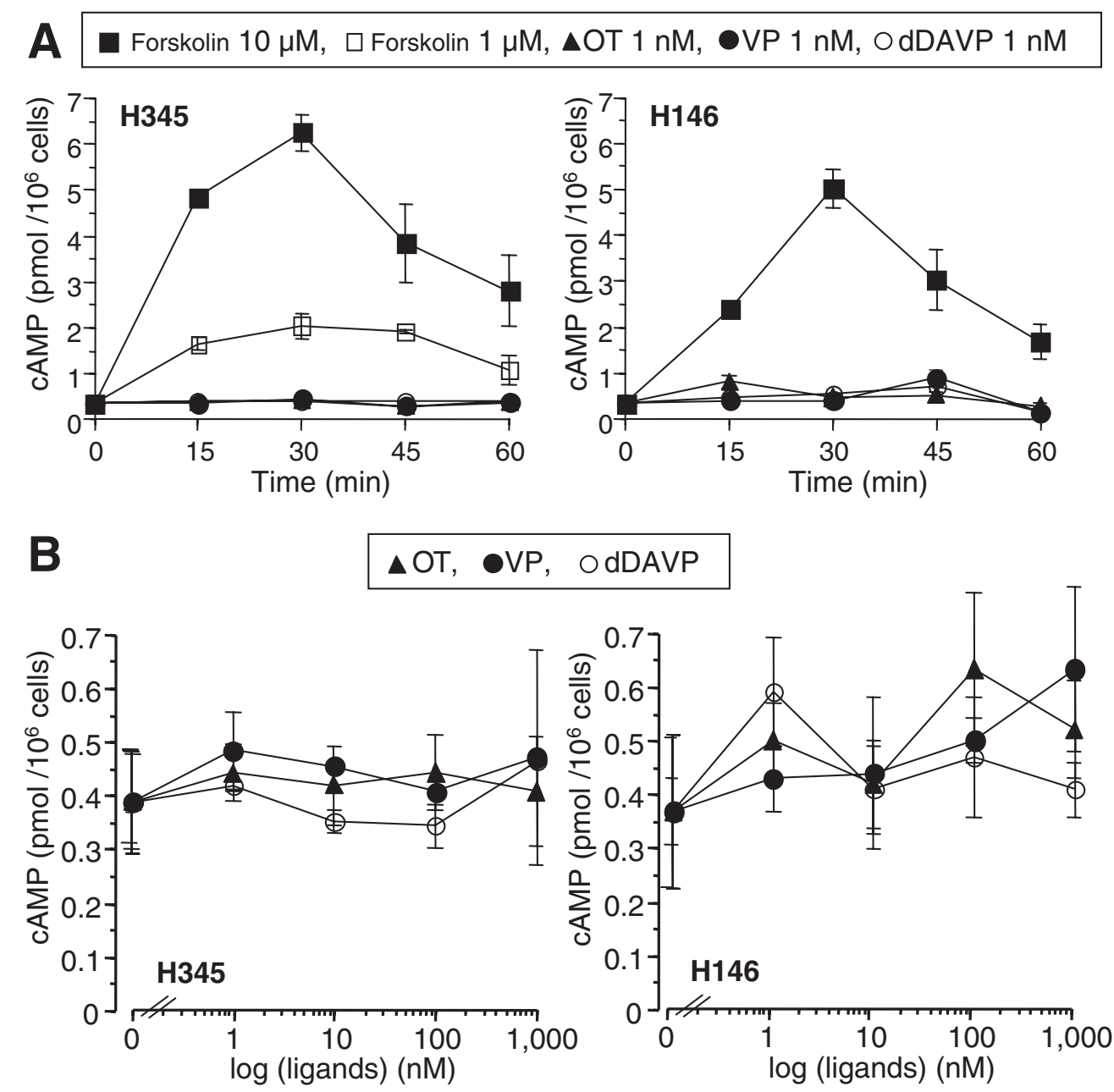

Figure 2 Effect of VP, dDAVP and OT on cAMP kinetics. (A) H345 or H146 cells were incubated with VP (O), dDAVP (O, V2R agonist) or OT ( $\mathbf{\Delta})$ at a ligand concentration of $1 \mathrm{nM}$, or with forskolin $(\square, 1 \mu \mathrm{M}$, or $\boldsymbol{\square}, 10 \mu \mathrm{M})$ used as a positive control, for 15 , 30, 45 or $60 \mathrm{~min}$. The amount of cAMP is expressed as pmol/ $10^{6}$ cells against time ( $\mathrm{min}$ ) ( $n=3$; mean \pm S.D.). (B) H345 or H146 cells were incubated with VP $(\bullet), \operatorname{dDAVP}(\bigcirc, \operatorname{V2R}$ agonist) or OT $(\boldsymbol{A})$ at agonist concentrations of $1,10,100$ or $1000 \mathrm{nM}$ for $30 \mathrm{~min}$. The amount of cAMP is expressed as pmol/ $10^{6}$ cells against log ligand concentration (nM) $(n=3$; mean \pm S.D.). Measurements were obtained by RIA on proteins extracted from H345 or H146 cytoplasm. Basal cAMP levels were determined at time 0 , prior to exposure to agonist.

with OT, VP, $\left[\mathrm{Thr}^{4}, \mathrm{Gly}^{7}\right] \mathrm{OT}$ or F180 at pharmacological concentrations. Pre-incubation with SR49059 almost completely blocked the increases of cytosolic $\mathrm{Ca}^{2+}$ induced by VP at $1 \mathrm{nM}$ or F180 at $20 \mathrm{nM}$, while OT at $1 \mathrm{nM}$ and $\left[\mathrm{Thr}^{4}, \mathrm{Gly}^{7}\right] \mathrm{OT}$ at $5 \mathrm{nM}$ were still able to elicit increases in the cytosolic $\mathrm{Ca}^{2+}$ levels. Pre-incubation with OVTA was able to block the OT-induced but not the VPinduced increase in cytosolic $\mathrm{Ca}^{2+}$ (Fig. 1).

\section{cAMP kinetics}

To discern whether adenylate cyclase-mediated signal transduction, generally associated with the V2R response, could be initiated in SCLC cells after stimulation with OT or VP, measurements of intracellular cAMP kinetics were performed on H345 and H146 cells. When the cells were incubated with VP, OT or the V2R agonist dDAVP, each at $1 \mathrm{nM}$, there was no increase observed in the intracellular cAMP levels, even after $60 \mathrm{~min}$ exposure (Fig. $2 \mathrm{~A})$. Various incubation times $(15-60 \mathrm{~min})$ and ligand concentrations ( $1 \mathrm{nM}$ to $1 \mu \mathrm{M})$ were tested; however, there were no significant changes in either SCLC cell line in the intracellular levels of cAMP detected. The results obtained from $\mathrm{H} 345$ and $\mathrm{H} 146$ cells after 30 min incubation with various ligand concentrations are shown in Fig. $2 \mathrm{~B}$. 

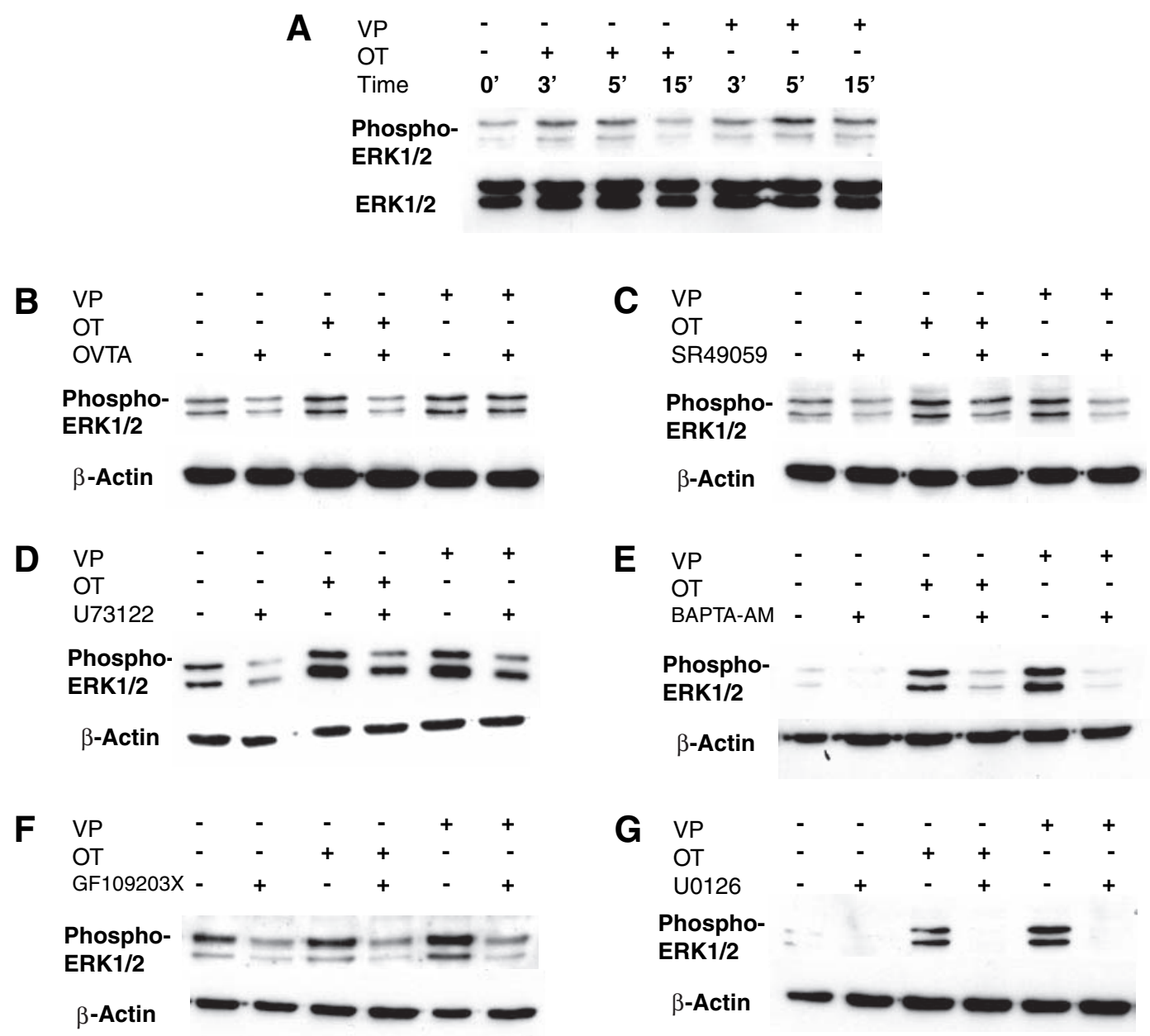

Figure 3 Effect of OT and VP on ERK1/2 phosphorylation with or without pre-incubation with specific signal transduction inhibitors. Proteins were extracted and separated by $10 \%$ SDS-PAGE and Western blot analysis was performed using a polyclonal antiphospho-ERK1/2 antibody. Cells were incubated $(+)$ or not $(-)$ with OT $(1 \mathrm{nM})$ or VP $(1 \mathrm{nM})$ for 3,5 and 15 min. A polyclonal antiERK1/2 antibody was used to normalize loading $(A)$. Cells were pre-incubated $(+)$ with OTR antagonist OVTA $(0.5 \mathrm{nM})(B)$, V1aR antagonist SR49059 $(10 \mathrm{nM})(\mathrm{C})$, or with solvent $(-)$ for $15 \mathrm{~min}$. Cells were pre-incubated $(+)$ with PLC inhibitor U73122 $(2.5 \mu \mathrm{M})$ (D), $\mathrm{Ca}^{2+}$ chelator BAPTA-AM $(20 \mu \mathrm{M})(\mathrm{E})$, PKC inhibitor GF109203X $(20 \mu \mathrm{M})(\mathrm{F}), \mathrm{MEK} 1 / 2$ inhibitor U0126 (10 $\left.\mu \mathrm{M}\right)(\mathrm{G})$, or with solvent (-) for $45 \mathrm{~min}$. Then, after these pre-incubations, cells were stimulated (+) or not (-) with OT (1 nM) or VP (1 nM) for $5 \mathrm{~min}$. A polyclonal anti- $\beta$-actin antibody was used to normalize loading. Western blots shown are representative of at least three independent experiments, each performed on $\mathrm{H} 345$ and $\mathrm{H} 146$ cells.

\section{OT- and VP-induced ERK1/2 phosphorylations and pathway}

MAPKs, and particularly ERK1/2, two highly conserved serine/threonine kinases activated via protein phosphorylation cascades, have been shown to be associated in proliferation processes of various cell types (Johnson \& Lapadat 2002). Moreover, phosphorylation of ERK $1 / 2$ is implicated in the growth of cells transfected with the OTR (Rimoldi et al. 2003) or the V1aR (Thibonnier et al. 2000). Therefore, SCLC H345 and H146 cells were treated with either OT or VP at $1 \mathrm{nM}$ and cell lysates were analysed for
ERK $1 / 2$ phosphorylation. After 5 min treatment, OT and VP induced comparable increases of ERK $1 / 2$ phosphorylation in both cell lines. There was a 3 -fold $(n=16)$ and a 2.5 -fold $(n=22)$ average OT- or VP-induced increase in ERK1/2 phosphorylation measured in $\mathrm{H} 345$ and H146 cells respectively, compared to the baseline levels of phospho-ERK $1 / 2$, and these increases started to decline after $15 \mathrm{~min}$ (Fig. 3A). Indeed, it must be noted that an ERK $1 / 2$ basal level of activation was usually observed in both SCLC cell lines (Fig. 3). Knowing that these cells secrete endogenous OT and VP (Péqueux et al. 2002), the effect of antagonists of these neuropeptides was evaluated 
Table 2 Quantified inhibition of basal ERK1/2 and p90 ${ }^{\mathrm{RSK}}$ phosphorylation after cell treatment with OT or VP antagonists. Means \pm S.D. are shown.

\begin{tabular}{llllll}
\hline & \multicolumn{2}{c}{$\begin{array}{c}\% \text { Basal ERK1/2 } \\
\text { phosphorylation inhibition }\end{array}$} & & & \multicolumn{2}{c}{$\begin{array}{c}\% \text { Basal p90 } \\
\text { phosphorylation inhibition }\end{array}$} \\
\cline { 2 - 3 } Antagonist & H345 cells & H146 cells & & H345 cells & H146 cells \\
\hline OVTA (OTR antagonist) & $28 \pm 6(n=4)$ & $30 \pm 7(n=3)$ & & $24 \pm 9(n=3)$ & $26 \pm 6(n=3)$ \\
SR49059 (V1aR antagonist) & $41 \pm 4(n=4)$ & $54 \pm 8(n=3)$ & & $38 \pm 7(n=7)$ & $30 \pm 10(n=3)$ \\
\hline
\end{tabular}

on the ERK1/2 basal level of phosphorylation. In both SCLC cell lines studied, the OTR antagonist OVTA and the V1aR antagonist SR49059, used at selective concentrations of 0.5 and $10 \mathrm{nM}$ respectively, reduced the basal level of phosphorylated ERK1/2 (Table 2, Fig. 3B and C). These antagonists were also used to check the specificity of ERK1/2 phosphorylation increases induced by exogenous OT and VP. In H345 and H146 cells, treatment with the OTR antagonist OVTA prevented OT-induced ERK1/2 phosphorylation, while it presented a minor effect on the VP-induced ERK1/2 phosphorylation (Table 3, Fig. 3B). Similarly, the effect of the VlaR antagonist SR49059 prevented VP-induced ERK1/2 phosphorylation, while its effect on the OT-induced ERK1/2 phosphorylation remained weaker (Table 3, Fig. 3C).

In order to identify the upstream mediators involved in the observed ERK1/2 phosphorylations, specific pharmacological inhibitors of signal transduction were examined for their effect on OT- and VP-induced ERK1/2 phosphorylation (Fig. 3, Table 3). OT and VP increase cytosolic $\mathrm{Ca}^{2+}$, and this pathway is activated when OTR or V1aR are coupled to $\mathrm{G} \alpha \mathrm{q} / 11$; thus contributions of PLC and $\mathrm{Ca}^{2+}$ to the mediation of ERK1/2 phosphorylation were examined. Pre-incubation of H345 and H146 cells with the PLC inhibitor U73122 (2.5 $\mu \mathrm{M}$; Fig. 3D) and the $\mathrm{Ca}^{2+}$ chelator BAPTA-AM $(20 \mu \mathrm{M}$; Fig. 3E) reduced OT- and VP-induced ERK1/2 phosphorylation in a similar manner in both cell lines (Table 3). OT- and VPinduced ERK 1/2 phosphorylation was downregulated by the PKC inhibitor GF109203X $(20 \mu \mathrm{M})$ similarly in both SCLC cells (Table 3, Fig. 3F). Moreover, these phosphorylations were almost completely blocked by the MEK $1 / 2$ inhibitor U0126 $(10 \mu \mathrm{M})$, confirming their specificity (Table 3, Fig. 3G).

\section{OT- and VP-induced $\mathrm{p} 90^{\mathrm{RSK}}$ phosphorylation}

A downstream target of ERK1/2 implicated in cell proliferation is the serine/threonine kinase p $90^{\text {RSK }}$ (Frodin \& Gammeltoft 1999). Incubation of SCLC H345 and H146 cells with OT or VP $(1 \mathrm{nM})$ induced an increase of p90 ${ }^{\text {RSK }}$ phosphorylation (Fig. 4). Compared to the basal level of $\mathrm{p} 90^{\mathrm{RSK}}$ phosphorylation observed in these cells, a 1.7 -fold $(n=15)$ and a 2.5 -fold $(n=13)$ average p90 RSK phosphorylation increase was observed after $5 \mathrm{~min}$ treatment with OT and VP respectively in H345 cells. Similarly in H146 cells, a 2-fold $(n=6)$ and a 3 -fold $(n=6)$ average $\mathrm{p} 90^{\mathrm{RSK}}$ phosphorylation increase was observed after 5 min treatment with OT and VP respectively. Next, OVTA and SR49059 were used to examine

Table 3 Quantified inhibition of OT- and VP-induced ERK1/2 and p90 ${ }^{\mathrm{RSK}}$ phosphorylation after cell treatment with pharmacological inhibitors and antagonists. Means \pm S.D. are shown

\begin{tabular}{|c|c|c|c|c|}
\hline \multirow[b]{2}{*}{ Inhibitors } & \multicolumn{2}{|c|}{ ОТ } & \multicolumn{2}{|c|}{ VP } \\
\hline & H345 cells & H146 cells & H345 cells & H146 cells \\
\hline \multicolumn{5}{|c|}{ \% ERK1/2 phosphorylation inhibition } \\
\hline OVTA (OTR antagonist) & $36 \pm 8 \quad(n=4)$ & $30 \pm 5(n=3)$ & $7 \pm 4 \quad(n=3)$ & $10 \pm 2 \quad(n=3)$ \\
\hline SR49059 (V1aR antagonist) & $20 \pm 10(n=4)$ & $21 \pm 6(n=3)$ & $54 \pm 7 \quad(n=7)$ & $68 \pm 10(n=3)$ \\
\hline U73122 (PLC inhibitor) & $72 \pm 10(n=3)$ & $76 \pm 9(n=3)$ & $85 \pm 9 \quad(n=3)$ & $86 \pm 11(n=3)$ \\
\hline BAPTA-AM $\left(\mathrm{Ca}^{2+}\right.$ chelator $)$ & $89 \pm 6 \quad(n=3)$ & $90 \pm 5(n=5)$ & $88 \pm 10(n=3)$ & $91 \pm 11(n=5)$ \\
\hline GF109203X (PKC inhibitor) & $63 \pm 9 \quad(n=3)$ & $77 \pm 8(n=6)$ & $72 \pm 8 \quad(n=3)$ & $74 \pm 6 \quad(n=6)$ \\
\hline U0126 (MEK1/2 inhibitor) & $91 \pm 7 \quad(n=3)$ & $94 \pm 4(n=4)$ & $95 \pm 3 \quad(n=3)$ & $97 \pm 5 \quad(n=4)$ \\
\hline \multicolumn{5}{|c|}{$\% 90^{\mathrm{RSK}}$ phosphorylation inhibition } \\
\hline OVTA (OTR antagonist) & $44 \pm 12(n=10)$ & $58 \pm 6(n=3)$ & $25 \pm 7 \quad(n=3)$ & $26 \pm 9 \quad(n=3)$ \\
\hline SR49059 (V1aR antagonist) & $23 \pm 12(n=10)$ & $12 \pm 5(n=3)$ & $56 \pm 13(n=4)$ & $49 \pm 10(n=3)$ \\
\hline GF109203X (PKC inhibitor) & $62 \pm 9 \quad(n=3)$ & $57 \pm 7(n=3)$ & $85 \pm 7 \quad(n=3)$ & $78 \pm 10(n=3)$ \\
\hline U0126 (MEK1/2 inhibitor) & $64 \pm 12(n=4)$ & $60 \pm 8(n=3)$ & $80 \pm 14(n=4)$ & $75 \pm 7 \quad(n=3)$ \\
\hline
\end{tabular}




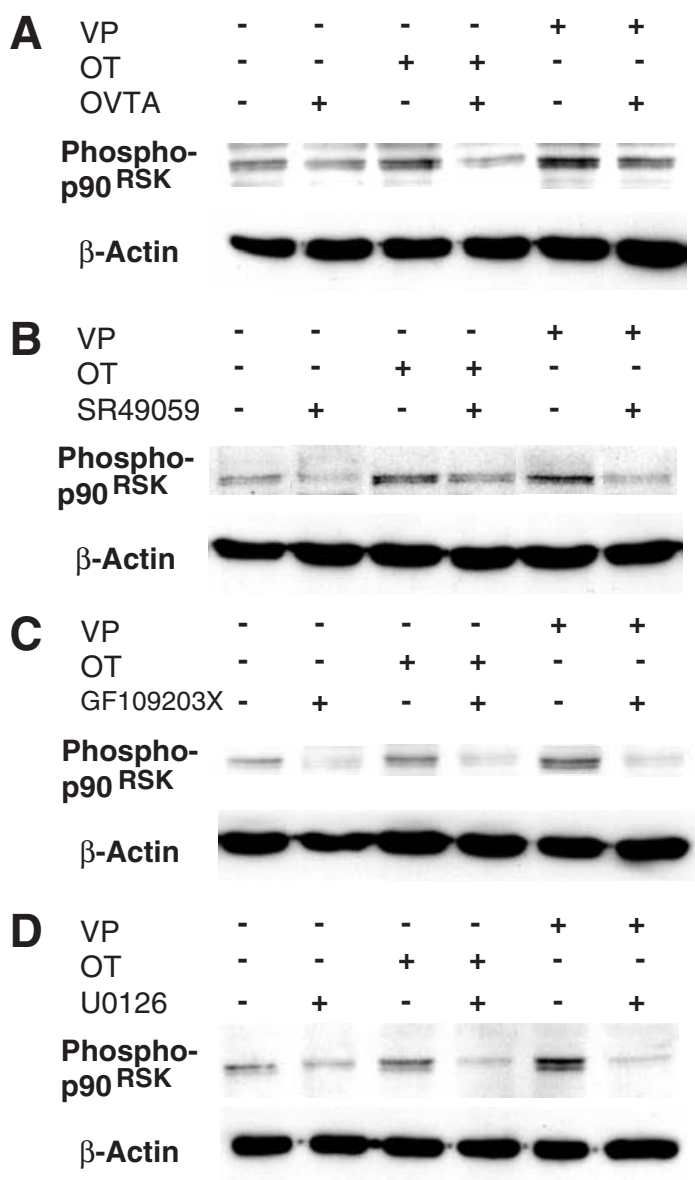

Figure 4 Effect of OT and VP on p90 ${ }^{\mathrm{RSK}}$ phosphorylation with or without pre-incubation with specific signal transduction inhibitors. Cells were pre-incubated $(+)$ with OTR antagonist OVTA $(0.5 \mathrm{nM})(\mathrm{A}), \mathrm{V} 1 \mathrm{aR}$ antagonist SR49059 (10 nM) (B) or with solvent $(-)$ for $15 \mathrm{~min}$. Cells were pre-incubated $(+)$ with PKC inhibitor GF109203X (20 $\mu \mathrm{M})(\mathrm{C})$, MEK1/2 inhibitor U0126 $(10 \mu \mathrm{M})(\mathrm{D})$ or with solvent $(-)$ for $45 \mathrm{~min}$. Then, after these preincubations, cells were stimulated $(+)$ or not $(-)$ with OT $(1 \mathrm{nM})$ or VP $(1 \mathrm{nM})$ for $5 \mathrm{~min}$. After extraction, proteins were separated by $10 \%$ SDS-PAGE and Western blot analysis was performed with a polyclonal anti-phospho-p90 ${ }^{\mathrm{RSK}}$ antibody. A polyclonal anti- $\beta$-actin antibody was used to normalize loading. Western blots shown are representative of at least three independent experiments, each performed on $\mathrm{H} 345$ and $\mathrm{H} 146$ cells.

the contribution of endogenous OT and VP to the basal level of $\mathrm{p} 90^{\mathrm{RSK}}$ phosphorylation observed in H345 and H146 cells. In both SCLC cell lines, OVTA and SR49059, used at selective concentrations of 0.5 and $10 \mathrm{nM}$ respectively, partially inhibited the $\mathrm{p} 90^{\mathrm{RSK}}$ basal level of phosphorylation in comparable proportions to what was observed for the ERK1/2 basal level of phosphorylation (Table 2, Fig. 4A and B). Incubation of H345 and H146 with the OTR antagonist OVTA reduced the stimulatory effect of exogenous OT on $\mathrm{p} 90^{\mathrm{RSK}}$ phosphorylation, and to a lesser extent the effect of the exogenous VP on p90 ${ }^{\text {RSK }}$ phosphorylation (Table 3, Fig. 4A). Similarly, treatment with the V1aR antagonist SR49059 resulted in a decrease in VP-induced $\mathrm{p} 90^{\mathrm{RSK}}$ phosphorylation, while its inhibition of OT-induced $\mathrm{p} 90^{\mathrm{RSK}}$ phosphorylation was weaker (Table 3, Fig. 4B). Moreover, the p90 ${ }^{\mathrm{RSK}}$ level of phosphorylation, resulting from the action of OVTA and SR49059 on OT- and VP-induced p90 ${ }^{\text {RSK }}$ phosphorylation respectively, was under the basal level of $\mathrm{p} 90^{\mathrm{RSK}}$ phosphorylation observed in these SCLC cells (Fig. 4A and $\mathrm{B})$.

PKC inhibitor GF109203X (20 $\mu \mathrm{M}$; Fig. 4C) and MEK1/2 inhibitor U0126 (10 $\mu \mathrm{M}$; Fig. 4D) downregulated OT- and VP-induced p90 RSK phosphorylation in both SCLC cell lines (Table 3). GF109203X and U0126 resulted in an acute decrease in VP-induced $\mathrm{p} 90^{\mathrm{RSK}}$ phosphorylation compared to the OT-induced $\mathrm{p} 90^{\mathrm{RSK}}$ phosphorylation.

\section{Inhibition of OT- and VP-induced mitogenic effect by acting on the OT- and VP-signalling pathway}

In order to define the signalling pathways contributing to the OT- and VP-induced mitogenic action on SCLC cellular growth, inhibitors described above were employed to determine their effects on $\mathrm{H} 345$ and $\mathrm{H} 146\left[{ }^{3} \mathrm{H}\right]$ thymidine incorporation experiments as a measure of proliferation (Fig. 5). We have demonstrated previously that OT and VP induce a significant increase in $\mathrm{H} 345$ cell proliferation (Péqueux et al. 2002). Both SCLC cell lines were therefore stimulated for $72 \mathrm{~h}$ with OT $(1 \mathrm{nM})$ or VP $(1 \mathrm{nM})$ prior to inhibitor addition. Compared to unstimulated cells, OT and VP treatments led to increases in H345 cellular growth of 20 and $35 \%$ respectively $(P<0.001)$, a range similar to that already described (Péqueux et al. 2002). These neuropeptides induced an increase in H146 cell proliferation as well. Indeed, H146 cellular growth was 15 and $20 \%$ higher after OT and VP stimulation respectively $(P<0.001$ compared with unstimulated cells; Fig. 5A). After $30 \mathrm{~min}$ inhibitor treatment, the OT- and VP-stimulated proliferation of H345 and H146 cells was significantly reduced by PLC inhibitor U73122 $(2.5 \mu \mathrm{M}), \mathrm{Ca}^{2+}$ chelator BAPTA-AM $(10 \mu \mathrm{M})$, PKC inhibitor GF109203X $(10 \mu \mathrm{M})$ and MEK1/2 inhibitor U0126 $(10 \mu \mathrm{M})$ (Fig. 5A). This effect persisted through $4 \mathrm{~h}$ of exposure to the inhibitors (time, $76 \mathrm{~h}$; Fig. 5C). Over $24 \mathrm{~h}$ of PLC inhibitor U73122 treatment (time, $96 \mathrm{~h}$ ) cells returned to their basal growth rate and then $\mathrm{H} 345$ cells remained quiescent through the $72 \mathrm{~h}$ incubation period while $\mathrm{H} 146$ cells continued to grow. The growth rates of cells incubated with $\mathrm{Ca}^{2+}$ chelator BAPTA-AM were $5-20 \%$ and $25-35 \%$ of basal levels for $\mathrm{H} 345$ and $\mathrm{H} 146$ cells respectively. After $24 \mathrm{~h}$ of 
A

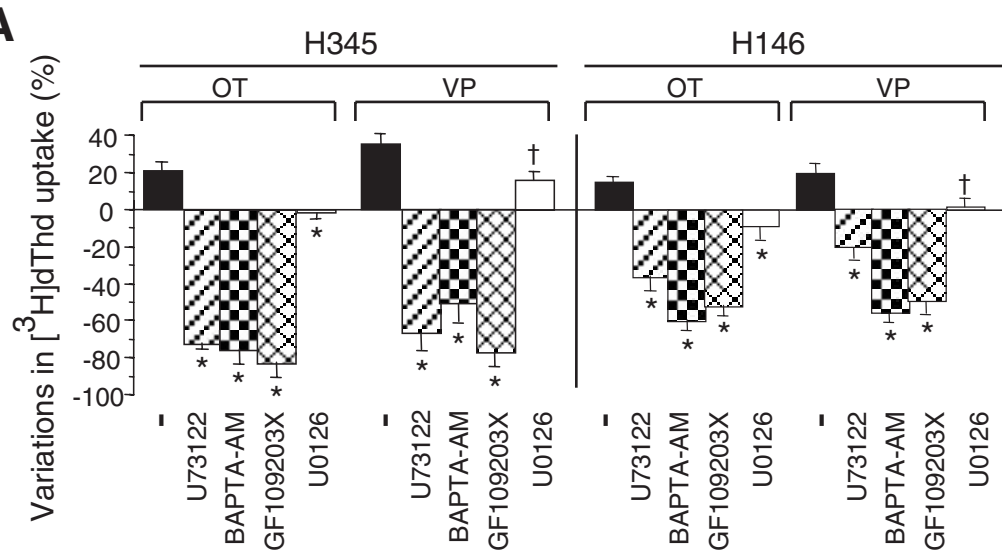

B
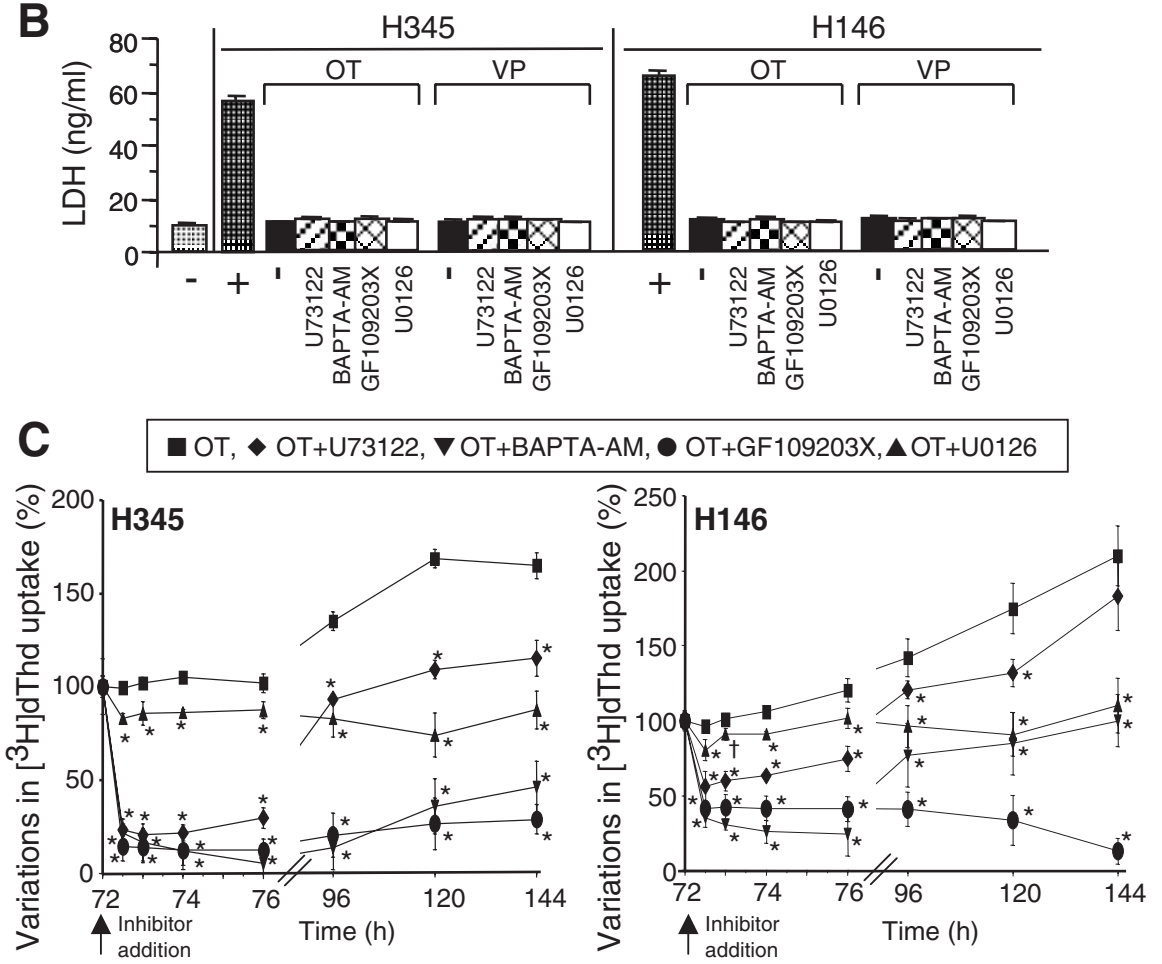

Figure 5 Effect of signalling pathway inhibitors on OT- and VP-stimulated SCLC H345 and H146 cellular growth. (A) Cellular growth of $\mathrm{H} 345$ and $\mathrm{H} 146$ cells was estimated by $\left[{ }^{3} \mathrm{H}\right]$ thymidine incorporation when cells were stimulated with OT or VP $(1 \mathrm{nM})$ for $72 \mathrm{~h}$, prior to addition of U73122 $(2.5 \mu \mathrm{M})$, BAPTA-AM $(10 \mu \mathrm{M})$, GF109203X $(10 \mu \mathrm{M})$, U0126 $(10 \mu \mathrm{M})$ or solvent $(-)$ for $30 \mathrm{~min}$. For each sample, the variation in $\left[{ }^{3} \mathrm{H}\right]$ thymidine incorporation was evaluated with respect to control unstimulated cultured $\mathrm{H} 345$ or $\mathrm{H} 146$ cells in at least three independent experiments each performed in quadruplicate. Data are expressed as percentage variations in $\left[{ }^{3} \mathrm{H}\right]$ thymidine $\left(\left[{ }^{3} \mathrm{H}\right] \mathrm{dTh}\right.$ ) uptake (means \pm S.D.; ${ }^{\dagger} P<0.05,{ }^{*} P<0.001$ ); U73122, BAPTA-AM, GF109203X or U0126 against solvent under OT- or VP-stimulated conditions. (B) LDH measurements in supernatants of H345 and H146 cells during OT- and VPstimulated proliferation experiments. LDH was measured in culture medium as negative control (-; left-hand bar) and in supernatants of cells stimulated with OT or VP $(1 \mathrm{nM})$ for $72 \mathrm{~h}$, then added to U73122 (2.5 $\mu \mathrm{M})$, BAPTA-AM $(10 \mu \mathrm{M})$, GF109203X $(10 \mu \mathrm{M}), \mathrm{U} 0126(10 \mu \mathrm{M})$ or solvent $(-$, black bars) for $30 \mathrm{~min}$. Positive control $(+)$ is LDH level obtained in supernatants when all $\mathrm{H} 345$ or $\mathrm{H} 146$ cells are lysed. Data are expressed as $\mathrm{LDH}(\mathrm{ng} / \mathrm{ml})$, means \pm S.D., $n=3$. (C). Proliferation of OT-stimulated H345 and $\mathrm{H} 146$ cells in the presence of U73122 $(2.5 \mu \mathrm{M}, \bullet)$, BAPTA-AM $(10 \mu \mathrm{M}, \boldsymbol{\nabla})$, GF109203X $(10 \mu \mathrm{M}, \boldsymbol{\bullet})$, U0126 $(10 \mu \mathrm{M}, \boldsymbol{\Delta})$ or solvent (ם) was estimated by $\left[{ }^{3} \mathrm{H}\right]$ thymidine incorporation in at least three independent experiments each performed in quadruplicate. $\mathrm{H} 345$ and $\mathrm{H} 146$ cells were stimulated with OT $(1 \mathrm{nM})$ for $72 \mathrm{~h}$ prior to inhibitor addition (time, $72 \mathrm{~h}$ ). Data are expressed as $\left[{ }^{3} \mathrm{H}\right]$ thymidine uptake (\%), (means \pm S.D.) against time (h), normalized for each sample to $100 \%$ at time $72 \mathrm{~h} ;{ }^{\dagger} P<0.05,{ }^{*} P<0.001 ;$ U 73122 , BAPTA-AM, GF109203X or U0126 against solvent under OT-stimulated conditions. 
incubation in the $\mathrm{Ca}^{2+}$ chelator (time, 96h), both cell lines reinitiated proliferation. PKC inhibitor GF109203X reduced the $\mathrm{H} 345$ and $\mathrm{H} 146$ cell proliferation rate to about 15 and $40 \%$ of the basal rate respectively, and both cell lines remained under $40 \%$ of the basal level throughout the exposure. In both cell lines the MEK $1 / 2$ inhibitor significantly prevented cellular proliferation and thus induced quiescence. This indicates that ERK $1 / 2$ is required in the $\mathrm{H} 345$ and $\mathrm{H} 146$ cell proliferation process.

During OT- and VP-stimulated proliferation assays, LDH measurements in supernatants of H345 and H146 cells remained at negative control level $(9.5 \pm 0.8 \mathrm{ng} / \mathrm{ml}$, $n=3$ ) from $30 \mathrm{~min}$ to $72 \mathrm{~h}$ of exposure with various inhibitors (Fig. 5B and results not shown). LDH values obtained from H345 and H146 cell lysates were $56.1 \pm$ $1.4 \mathrm{ng} / \mathrm{ml}(n=3)$ and $65.2 \pm 1.5 \mathrm{ng} / \mathrm{ml}(n=3)$ respectively. Altogether, these results demonstrate that signalling inhibitors, used in proliferation assays, do not induce cell lysis and therefore growth inhibitions are not a consequence of toxicity. In addition, the absence of toxicity was confirmed by re-establishment of cell growth after treatment (Fig. 5C). Proliferation curves obtained for H345 and H146 cells under VP-stimulated conditions (results not shown) were comparable to those obtained under OT-stimulated conditions (Fig. 5C).

\section{Discussion}

Neurohypophysial peptides are involved in potent autocrine/paracrine signalling loops which are essential for cellular growth processes developed by SCLC tumours during oncogenesis (North 2000, Péqueux et al. 2002, Rozengurt 2002). The fact that all neurohypophysial peptide GPCRs are expressed by SCLC cells suggest that OT- and VP-initiated signalling is part of a complex array of interactions culminating in the development of these tumours (North et al. 1998b, Péqueux et al. 2002). Therefore, understanding the mechanistic action of such hormones and their respective receptors in SCLC cellular growth is essential for the development of new and specific therapeutics.

To define the signalling pathways leading to OT- and VP-induced mitogenic effects on SCLC, the two major signal transduction mechanisms proposed to be associated with the neurohypophysial peptide GPCRs (Barberis et al. 1998) were examined: (1) the inositol-mediated pathway (which is generally associated with OTR, V1aR or V1bR/ V3R activation) leading to increases in cytosolic $\mathrm{Ca}^{2+}$ and (2) the adenylate cyclase-mediated pathway (which is principally associated with $\mathrm{V} 2 \mathrm{R}$ activation) leading to increases in cAMP, and which has also been shown to be activated by OT (Cassoni et al. 1997, 1998). By stimulating H345 SCLC cells with the OTR agonist [Thr ${ }^{4}$,
Gly ${ }^{7}$ OOT and with the V1aR agonist F180 at selective concentrations of 5 and $20 \mathrm{nM}$ respectively, we have demonstrated that the cell surface-expressed OTR and V1aR are functional as they can mediate increases in cytosolic $\mathrm{Ca}^{2+}$. OT-induced increases in cytosolic $\mathrm{Ca}^{2+}$ levels were found to be comparable to those observed after VP stimulation. Since these increases could be blocked using antagonists to OTR or V1aR, it appears that those receptors are responsible for mediating the majority of the OT- or VP-induced increases in cytosolic $\mathrm{Ca}^{2+}$ levels. Additionally, we have shown that neither OT, VP nor dDAVP (V2R agonist) was able to alter the cAMP levels in the two SCLC cell lines H345 and H146, under the conditions used in the following study.

Although a previous study showed that elevations in cytosolic $\mathrm{Ca}^{2+}$ can be induced by OT (Hong \& Moody 1991), they were obtained using ligand concentrations in the range of $0.1-10 \mu \mathrm{M}$. The use of such high concentrations raised the probability that this $\mathrm{Ca}^{2+}$ response to OT was mediated by VP receptors. In the experiments presented here we performed $\mathrm{Ca}^{2+}$ kinetics using $1 \mathrm{nM}$ OT, which corresponds to the order of magnitude of the $K_{\mathrm{d}}$ value of OT towards its receptor. We also demonstrated that the cytosolic $\mathrm{Ca}^{2+}$ elevation induced by this level of OT was mediated principally through the OTR and not the V1aR. First, OT was able to elicit an increase in $\mathrm{Ca}^{2+}$ in the presence of the V1aR antagonist SR49059 $(10 \mathrm{nM})$ and secondly this increase could be abolished by the OTR antagonist OVTA $(0.5 \mathrm{nM})$ thus indicating specific activation of OTR by OT. VP has already been demonstrated to elevate cytosolic $\mathrm{Ca}^{2+}$ in various SCLC cell lines and particularly in H345 cells (Woll \& Rozengurt 1989b, Hong \& Moody 1991, Bunn et al. 1994, North et al. 1997), but we further examined the effects of VP at the physiological range of $1 \mathrm{nM}$ and established that the $\mathrm{Ca}^{2+}$ signal induced at this concentration is largely mediated by the V1aR. Indeed, the V1aR antagonist SR49059 (10 nM) almost completely inhibits the $\mathrm{Ca}^{2+}$ signal, whereas OVTA (OTR antagonist) has no measurable effect. For the experimental conditions used here, we were not able to demonstrate any detectable increase in cAMP, in two different SCLC cell lines, in response to VP, dDAVP (V2R agonist) or OT over a wide range of concentrations $(1 \mathrm{nM}-1 \mu \mathrm{M})$. These data suggest that the action of VP at V2R in H345 and H146 cells does not normally produce an activation of the adenylate cyclase cascade. This may be a result of the expression of an abnormally truncated V2R form by these cells, which may block V2R function (North et al. 1998a,b). The lack of an OT-dependent cAMP pathway, the presence of an OT-activated $\mathrm{Ca}^{2+}$ response, and a clear mitogenic effect of OT observed on H345 and H146 SCLC cells (Péqueux et al. 2002 and data shown here) is in agreement with the conclusions of 
Bussolati, Cassoni and colleagues (Bussolati \& Cassoni 2001, Cassoni et al. 2001). Indeed, the latter report associated the cAMP pathway with an anti-proliferative effect, and the $\mathrm{Ca}^{2+}$ cascade with proliferative effects.

To further identify the impact of OT and VP on the SCLC mitogenic response, the induced phosphorylation of ERK1/2 and p90 ${ }^{\text {RSK }}$ was assessed on two different SCLC cell lines. Our results indicate that stimulation of SCLC with exogenous OT or VP $(1 \mathrm{nM})$ mediates an increase in phosphorylation of ERK $1 / 2$ and of its downstream target $\mathrm{p} 90^{\mathrm{RSK}}$, peaking $5 \mathrm{~min}$ after exposure. Since studies of $\mathrm{Ca}^{2+}$ kinetics indicated that at the hormone concentration used there was specific activation of OTR and V1aR, it appears that increases in ERK1/2 and $\mathrm{p} 90^{\mathrm{RSK}}$ phosphorylation are also regulated by these receptors. Moreover, the OTR antagonist OVTA and the V1aR antagonist SR49059 reduced the basal level of ERK $1 / 2$ and $\mathrm{p} 90^{\mathrm{RSK}}$ phosphorylation in both SCLC cell lines, demonstrating that endogenously produced OT and VP contribute to this basal level of MAPK activation in SCLC. Additionally, ERK $1 / 2$ and $\mathrm{p} 90^{\mathrm{RSK}}$ phosphorylation induced by exogenous OT or VP was inhibited by OVTA or SR49059 respectively, indicating that the actions of these hormones are mediated primarily through their corresponding receptors. It must be noted that SCLC secretes various neuropeptides, which were shown to activate MAPK phosphorylation as well (Rozengurt 2002). The impact of specific inhibitors of signal transduction intermediates, tested with OT- and VPinitiated increases of ERK1/2 phosphorylation, suggests the involvement of PLC-, $\mathrm{Ca}^{2+}$ - and PKC-dependent pathways. Similarly, OT- and VP-induced p $90^{\mathrm{RSK}}$ phosphorylation was PKC-dependent. Moreover, the use of these inhibitors in $\left[{ }^{3} \mathrm{H}\right]$ thymidine-uptake assays indicates that PLC, $\mathrm{Ca}^{2+}, \mathrm{PKC}$ and ERK1/2 are essential in the OT- and VP-stimulated H345 and H146 SCLC cellular growth process. Indeed, arrest of cellular growth was not due to toxicity, but rather to blocking of mitogenic transduction cascades.

The VP-induced phospho-ERK1/2 activation we observed in H345 SCLC cells corroborates findings of Seufferlein \& Rozengurt (1996). However, the VP dose they used was $100 \mathrm{nM}$. Thus, the $1 \mathrm{nM}$ concentration used in this study was chosen to dissect specific contributions from each neurohypophysial peptide and to further analyze the upstream pathway leading to the phosphorylation of ERK1/2, as well as its downstream target p90 ${ }^{\mathrm{RSK}}$. We demonstrated that in H345 and H146 SCLC cells OT- and VP-induced phospho-ERK1/2 activation was transient and PLC-, $\mathrm{Ca}^{2+}$ - and PKC-dependent. These results are in agreement with the VP-mediated mitogenic signalling studied in rat intestinal epithelial cells (Chiu et al. 2002) and in V1aR-transfected cells (Thibon- nier et al. 2000), where this ERK1/2-associated pathway could be activated simultaneously with $\mathrm{Ca}^{2+} /$ calmodulin kinase II and phosphoinositide 3-kinase cascades. The transient OT-induced ERK1/2 phosphorylation detected in SCLC H345 and H146 cells is in agreement with data obtained on human uterine myometrial cells and on OTRtransfected cells (Ohmichi et al. 1995, Strakova et al. 1998). In addition, Rimoldi et al. (2003) showed that an OT-induced mitogenic effect, related to OTR located in caveolin-enriched microdomains, was indeed mediated through transient activation, whereas an OT-induced anti-proliferative effect was associated with sustained ERK1/2 phosphorylation. The PLC inhibitor U73122 was shown to prevent the growth of OTR-transfected HEK293 cells; however, it did not inhibit the growth of HEK-293 cells that expressed an OTR-caveolin 2 construct, which had the effect of localizing the OTR to caveolin-enriched microdomains (Rimoldi et al. 2003). In H345 and H146 SCLC cells, we observed that PLC inhibitor U73122 abolished phospho-ERK1/2 activation and cellular growth, which indicates that H345 and H146 cellular growth is dependent on PLC-mediated signalling and that OTR may not be associated with caveolinenriched surface invaginations of these cells. Combine this with the facts that OT induced cytosolic $\mathrm{Ca}^{2+}$ increase and that $\mathrm{Ca}^{2+}$ is absolutely required for OT-stimulated SCLC proliferation, the PLC-dependent OT-induced cellular growth pathway demonstrated in this study supports the coupling of OTR to $\mathrm{G} \alpha \mathrm{q} / 11$, when G $\alpha \mathrm{i}$ mediates the PLC-dependent inhibitory response of OT in OTR-transfected HEK-293 cells (Rimoldi et al. 2003). The downstream ERK1/2 target $\mathrm{p} 90^{\mathrm{RSK}}$ is involved in the regulation of gene expression and protein synthesis, as well as in the cell-cycle progression through regulation of various components of the cell-cycle machinery (Frodin \& Gammeltoft 1999, Willard \& Crouch 2001). We observed that inhibitors of PKC and MEK1/2 abolished the OTand VP-induced p90 ${ }^{\mathrm{RSK}}$ phosphorylation and inhibited H345 and H146 SCLC cellular growth. Similarly, the inhibition of $\mathrm{p} 90^{\mathrm{RSK}}$ was shown to abolish growth stimulation of multicellular prostate tumour spheroids (Sauer et al. 2001). Inhibition of PKC also exhibits antitumour activity in various cancer types, in studies in vitro and in clinical trials (Mackay \& Twelves 2003). Thus our observations are in support of factors involved in cellular growth and differentiation transduction signalling representing potential targets for anticancer therapy.

In conclusion, we demonstrate that, under pharmacological and physiological levels, OT- and VP-induced mitogenic effects on SCLC pass through the specific and respective binding of OTR and $\mathrm{V} 1 \mathrm{aR}$ and culminate in the activation of ERK $1 / 2$ and $\mathrm{p} 90^{\mathrm{RSK}}$ phosphorylation through PLC-, $\mathrm{Ca}^{2+}$-, PKC- and MEK1/2-dependent 


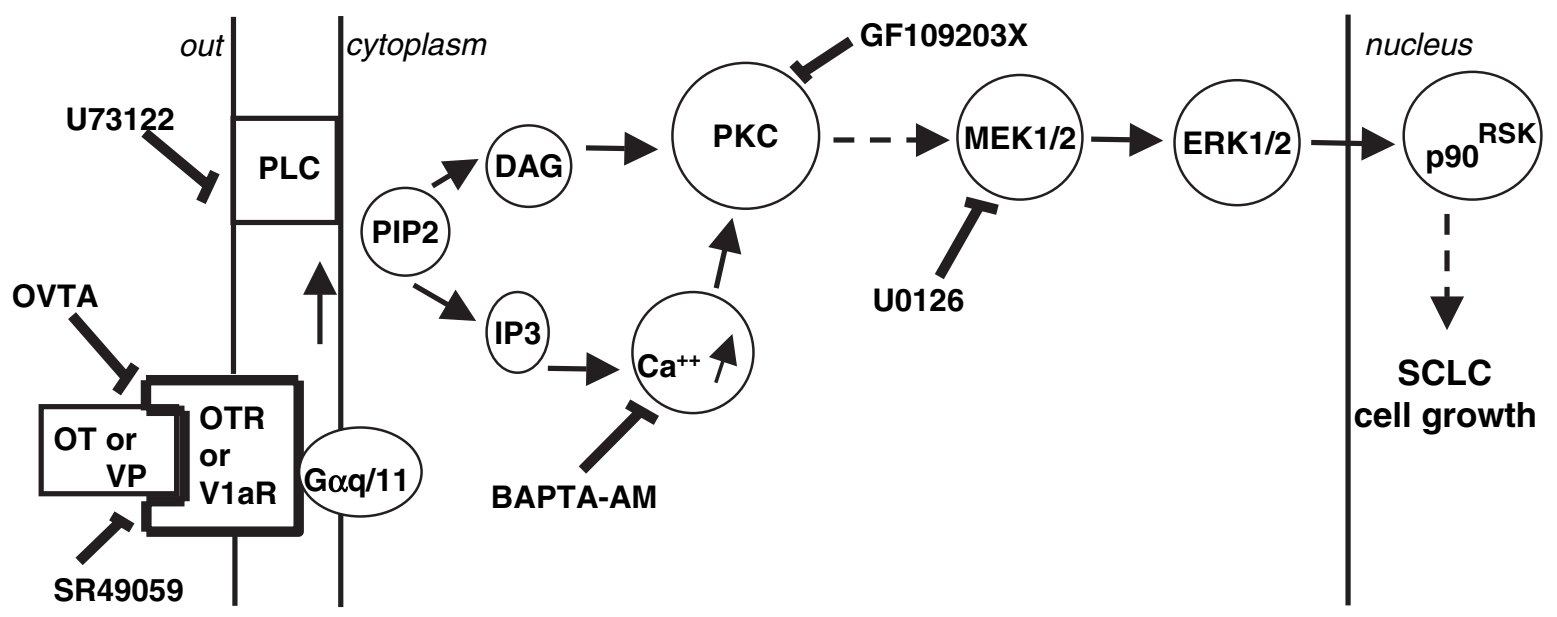

Figure 6 Schematic model of the OT- and VP-induced mitogenic signalling pathway in SCLC. Direct and indirect activations are represented by plain and broken arrows respectively. Sites of action of OVTA, SR49059, U73122, BAPTA-AM, GF109203X and U0126 are shown by heavy stopped lines. OT- and VP-induced mitogenic effects in SCLC are mediated by the coupling of the OTR and the V1aR to G $\alpha q / 11$ respectively, resulting in ERK1/2 and p90 ${ }^{\mathrm{RSK}}$ phosphorylation through PLC-, Ca ${ }^{2+}-$, PKC- and MEK1/2dependent pathways.

pathways (Fig. 6). Moreover, we demonstrate that growth of OT- and VP-stimulated SCLC could be downregulated by signalling inhibitors and was not a consequence of toxicity. Thus the results identify pathways activated by OT- and VP-mitogenic action on SCLC and show that blocking of their receptor signalling represents viable pharmacological targets for the treatment of neuroendocrine tumours expressing autocrine/paracrine neurohypophysial system loops, such as SCLC.

\section{Acknowledgments}

The authors would like to thank Andrea Osborne, Mary Cippolone, Alison North and Isabelle Hansenne for excellent assistance, Dr A. Givan and $\mathrm{Mr}$ G. Ward (Herbert C. Englert Cell Analysis Laboratory, Dartmouth Medical School, NH, USA) for help with the flowcytometric calcium analysis, Dr G. Guillon (INSERM U 469, Montpellier, France) for pharmacological guidelines, as well as Dr P. Riviere (Ferring, Research, USA), Dr M. Manning (Medical College of Ohio, OH, USA) and Dr C. Serradeil-Le Gal (Sanofi, France) for the gift of F180, $\left[\mathrm{Thr}^{4}\right.$, Gly $\left.{ }^{7}\right]$ OT and SR49059 respectively. We are also grateful to Dr A. Péqueux, Dr F. Brilot and Dr S. Turville for critical reviews of the manuscript and discussions.

\section{Funding}

This work was supported in part by US Public Health Service grants CA 19613 from the National Cancer Institute and T32-DK 07508 from NIDDK, by a Belgian
FNRS-FRSM grant (3.4537.01) and by the Belgian Federation against Cancer. C Péqueux is supported as a PhD by Belgian FNRS-Télévie (grant no. 7.4605.03) and by the Foundation Léon Fredericq (Liège University Medical School, Belgium). Flow-cytometric analyses were performed at Dartmouth Medical School in the Herbert C. Englert Cell Analysis Laboratory, which was established by a grant from the Fannie E. Rippel Foundation and is supported in part by the Core Grant of the Norris Cotton Cancer Center (CA, USA).

\section{References}

Andres M, Trueba M \& Guillon G 2002 Pharmacological characterization of F-180: a selective human V(1a) vasopressin receptor agonist of high affinity. British Journal of Pharmacology 135 1828-1836.

Aurell C, Bengtsson B, Ekholm K, Kasprzykowska R, Nilsson A, Persson A, Trojnar J, Abbe M \& Melin P 1990 Development of vasopressor specific vasotocin analogues with prolonged effects. In Peptides, pp 671-673. Eds E Giralt \& D Andreu. Leiden, The Netherlands: ESCOM Science Publishers.

Barberis C, Mouillac B \& Durroux T 1998 Structural bases of vasopressin/oxytocin receptor function. Journal of Endocrinology $156223-229$.

Barberis C, Morin D, Durroux T, Mouillac B, Guillon G, Seyer R, Hibert M, Tribollet E \& Manning M 1999 Molecular pharmacology of AVP and OT receptors and therapeutic potential. Drug News Perspective 12 279-292.

Birnbaumer M, Seibold A, Gilbert S, Ishido M, Barberis C, Antaramian A, Brabet P \& Rosenthal W 1992 Molecular cloning of the receptor for human antidiuretic hormone. Nature 357 333-335. 
Bunn PA Jr, Chan D, Stewart J, Gera L, Tolley R, Jewett P, Tagawa M, Alford C, Mochzuki T \& Yanaihara N 1994 Effects of neuropeptide analogues on calcium flux and proliferation in lung cancer cell lines. Cancer Research $\mathbf{5 4}$ 3602-3610.

Bussolati G \& Cassoni P 2001 Editorial: the oxytocin/oxytocin receptor system-expect the unexpected. Endocrinology 142 1377-1379.

Cassoni P, Sapino A, Fortunati N, Munaron L, Chini B \& Bussolati G 1997 Oxytocin inhibits the proliferation of MDAMB231 human breast-cancer cells via cyclic adenosine monophosphate and protein kinase A. International Journal of Cancer 72 340-344.

Cassoni P, Sapino A, Stella A \& Bussolati G 1998 Antiproliferative effect of oxytocin through specific oxytocin receptors in human neuroblastoma and astrocytoma cell lines. Advances in Experimental Medicine and Biology 449 245-246.

Cassoni P, Marrocco T, Deaglio S, Sapino A \& Bussolati G 2001 Biological relevance of oxytocin and oxytocin receptors in cancer cells and primary tumors. Annals of Oncology $\mathbf{1 2}$ S37-S39.

Cassoni P, Sapino A, Deaglio S, Bussolati B, Volante M, Munaron L, Albini A, Torrisi A \& Bussolati G 2002 Oxytocin is a growth factor for Kaposi's sarcoma cells: evidence of endocrine-immunological cross-talk. Cancer Research 62 2406-2413.

Chiu T, Wu SS, Santiskulvong C, Tangkijvanich P, Yee HF Jr \& Rozengurt E 2002 Vasopressin-mediated mitogenic signaling in intestinal epithelial cells. American Journal of Physiology, Cell Physiology 282 C434-C450.

de Keyzer Y, Auzan C, Lenne F, Beldjord C, Thibonnier M, Bertagna X \& Clauser E 1994 Cloning and characterization of the human $\mathrm{V} 3$ pituitary vasopressin receptor. FEBS Letters 356 215-220.

Devost D \& Zingg HH 2004 Homo- and hetero-dimeric complex formations of the human oxytocin receptor. Journal of Neuroendocrinology 16 372-377.

Friedmann AS, Malott KA, Memoli VA, Pai SI, Yu XM \& North WG 1994 Products of vasopressin gene expression in small-cell carcinoma of the lung. British Journal of Cancer 69 260-263.

Frodin M \& Gammeltoft S 1999 Role and regulation of $90 \mathrm{kDa}$ ribosomal S6 kinase (RSK) in signal transduction. Molecular and Cellular Endocrinology 151 65-77.

Guzzi F, Zanchetta D, Cassoni P, Guzzi V, Francolini M, Parenti M \& Chini B 2002 Localization of the human oxytocin receptor in caveolin-1 enriched domains turns the receptormediated inhibition of cell growth into a proliferative response. Oncogene 21 1658-1667.

Hanahan D \& Weinberg RA 2000 The hallmarks of cancer. Cell $10057-70$.

Heasley LE 2001 Autocrine and paracrine signaling through neuropeptide receptors in human cancer. Oncogene $\mathbf{2 0}$ 1563-1569.

Hong M \& Moody TW 1991 Vasopressin elevates cytosolic calcium in small cell lung cancer cells. Peptides 12 1315-1319.

Jard S 1998 Vasopressin receptors. A historical survey. In Advances in Experimental Medicine and Biology, pp 1-13. Eds
HH Zing, CW Bourque \& DG Bichet. New York: Plenum Press.

Johnson GL \& Lapadat R 2002 Mitogen-activated protein kinase pathways mediated by ERK, JNK, and p38 protein kinases. Science 298 1911-1912.

Kimura T, Tanizawa O, Mori K, Brownstein MJ \& Okayama $\mathrm{H}$ 1992 Structure and expression of a human oxytocin receptor. Nature 356 526-529 [published erratum appears in Nature 357 176].

Lowbridge J, Manning M, Haldar J \& Sawyer WH 1977 Synthesis and some pharmacological properties of [4threonine, 7-glycine]oxytocin, [1-(L-2-hydroxy-3mercaptopropanoic acid), 4-threonine, 7-glycine]oxytocin (hydroxy[Thr4, Gly7]oxytocin), and [7-Glycine]oxytocin, peptides with high oxytocic-antidiuretic selectivity. Journal of Medicinal Chemistry 20 120-123.

Mackay HJ \& Twelves CJ 2003 Protein kinase C: a target for anticancer drugs? Endocrine-Related Cancer 10 389-396.

Manning M, Kruszynski M, Bankowski K, Olma A, Lammek B, Cheng LL, Klis WA, Seto J, Haldar J \& Sawyer WH 1989 Solid-phase synthesis of 16 potent (selective and nonselective) in vivo antagonists of oxytocin. Journal of Medicinal Chemistry 32 382-391.

North WG 2000 Gene regulation of vasopressin and vasopressin receptors in cancer. Experimental Physiology 85 27S-40S.

North WG, Friedmann AS \& Yu X 1993 Tumor biosynthesis of vasopressin and oxytocin. Annals of the New York Academy of Science 689 107-121.

North WG, Fay MJ, Longo K \& Du J 1997 Functional vasopressin V1 type receptors are present in variant as well as classical forms of small-cell carcinoma. Peptides 18 985-993.

North WG, Fay MJ \& Du J 1998a All three vasopressin receptor sub-types are expressed by small-cell carcinoma. Advances in Experimental Medicine and Biology 449 335-338.

North WG, Fay MJ, Longo KA \& Du J 1998 Expression of all known vasopressin receptor subtypes by small cell tumors implies a multifaceted role for this neuropeptide. Cancer Research 58 1866-1871.

Ohmichi M, Koike K, Nohara A, Kanda Y, Sakamoto Y, Xian Zhang Z, Hirota K \& Miyake A 1995 Oxytocin stimulates mitogen-activated protein kinase activity in cultured human puerperal uterine myometrial cells. Endocrinology 136 2082-2087.

Péqueux C, Breton C, Hendrick J-C, Hagelstein M-T, Martens H, Winkler R, Geenen V \& Legros J-J 2002 Oxytocin synthesis and oxytocin receptor expression by cell lines of human small cell carcinoma of the lung stimulate tumor growth through an autocrine/paracrine signaling. Cancer Research 62 4623-4629.

Rimoldi V, Reversi A, Taverna E, Rosa P, Francolini M, Cassoni P, Parenti M \& Chini B 2003 Oxytocin receptor elicits different EGFR/MAPK activation patterns depending on its localization in caveolin-1 enriched domains. Oncogene 22 6054-6060.

Rozengurt E 2002 Neuropeptides as growth factors for normal and cancerous cells. Trends in Endocrinology and Metabolism 13 128-134.

Sauer H, Klimm B, Hescheler J \& Wartenberg M 2001 Activation of p90RSK and growth stimulation of multicellular tumor 
spheroids are dependent on reactive oxygen species generated after purinergic receptor stimulation by ATP. FASEB Journal 15 2539-2541.

Serradeil-Le Gal C, Wagnon J, Garcia C, Lacour C, Guiraudou P, Christophe B, Villanova G, Nisato D, Maffrand JP, Le Fur G, et al. 1993 Biochemical and pharmacological properties of SR 49059, a new, potent, nonpeptide antagonist of rat and human vasopressin V1a receptors. Journal of Clinical Investigation 92 224-231.

Sethi T \& Rozengurt E 1991 Multiple neuropeptides stimulate clonal growth of small cell lung cancer: effects of bradykinin, vasopressin, cholecystokinin, galanin, and neurotensin. Cancer Research 51 3621-3623.

Seufferlein T \& Rozengurt E 1996 Galanin, neurotensin, and phorbol esters rapidly stimulate activation of mitogenactivated protein kinase in small cell lung cancer cells. Cancer Research 56 5758-5764.

Strakova Z, Copland JA, Lolait SJ \& Soloff MS 1998 ERK2 mediates oxytocin-stimulated PGE2 synthesis. American Journal of Physiology, Endocrinology and Metabolism 274 E634-E641.

Sugimoto T, Saito M, Mochizuki S, Watanabe Y, Hashimoto S \& Kawashimah 1994 Molecular cloning and functional expression of a cDNA encoding the human V1b vasopressin receptor. Journal of Biological Chemistry 269 27088-27092.

Terrillon S, Durroux T, Mouillac B, Breit A, Ayoub MA, Taulan M, Jockers R, Barberis C \& Bouvier M 2003 Oxytocin and vasopressin $\mathrm{V} 1 \mathrm{a}$ and $\mathrm{V} 2$ receptors form constitutive homo- and heterodimers during biosynthesis. Molecular Endocrinology 17 677-691.

Thibonnier M, Auzan C, Madhun Z, Wilkins P, Berti-Mattera L \& Clauser E 1994 Molecular cloning, sequencing, and functional expression of a cDNA encoding the human V1a vasopressin receptor. Journal of Biological Chemistry 269 3304-3310.

Thibonnier M, Conarty DM \& Plesnicher CL 2000 Mediators of the mitogenic action of human $\mathrm{V}(1)$ vascular vasopressin receptors. American Journal of Physiology, Heart and Circulatory Physiology 279 H2529-H2539.

Willard FS \& Crouch MF 2001 MEK, ERK, and p90RSK are present on mitotic tubulin in Swiss 3T3 cells: a role for the MAP kinase pathway in regulating mitotic exit. Cellular Signalling 13 653-664.

Woll PJ \& Rozengurt E $1989 a$ Neuropeptides as growth regulators. British Medicine Bulletin 45 492-505.

Woll PJ \& Rozengurt E 1989 b Multiple neuropeptides mobilise calcium in small cell lung cancer: effects of vasopressin, bradykinin, cholecystokinin, galanin and neurotensin. Biochemistry and Biophysics Research Communication 164 66-73.

Zaoral M, Kolc J \& Sorm F 1967 Synthesis of 1-desamino-8-Dlysine vasopressin and 1-desamino-D-arginine vasopressin. Collection of Czech Chemistry Communication 32 1250-1257.

Zingg HH \& Laporte SA 2003 The oxytocin receptor. Trends in Endocrinology and Metabolism 14 222-227.

Zochbauer-Muller S, Gazdar AF \& Minna JD 2002 Molecular pathogenesis of lung cancer. Annual Review of Physiology 64 681-708. 